\title{
Investigation of Effective Treatment Techniques for Olive Mill wastewater
}

\author{
Enas M. Abou-Taleb, Gamal Kamel, Mohamed S. Hellal* \\ Water Pollution Research Department, National Research Centre, 33 Behooth St., \\ P.O. Box 12622, Dokki, Giza, Egypt
}

\begin{abstract}
QELECTION of cost-effective treatment modules for high saline wastewater produced from the olive mill is a challenging task. The aim of this study is to select the most effective technology applied to treat Olive mill wastewater. Several trials using various techniques were carried out to treat wastewater produced from pickling olives and olive oil manufacturing; for instance, anaerobic-aerobic, coagulation/flocculation, and electrocoagulation. The characteristics of olive manufacturing raw wastewater in terms of total dissolved solids (TDS), chemical oxygen demand (COD) and oil and grease were 10032, 9174, and 914.8 mg/1 respectively. The results showed that electro-coagulation technique with aluminum electrodes and operating parameters of 30 voltage and 1.5 hours achieved COD removal rate $84 \%$. However, the residual concentration $\left(900 \mathrm{mgO}_{2} / \mathrm{l}\right)$ still needs further treatment. Aerobic treatment using activated sludge was applied after electrocoagulation. The results showed that the use aerobic treatment after electrocoagulation is more efficient than the use of anaerobic. Analysis of the treated water showed that the maximum COD removal efficiencies were $98 \%$ at optimum conditions. The effluent quality meets the discharge regulatory standard. Consequently, the electrocoagulation followed by aerobic process can be considered as a reliable, safe and costeffective method for the treatment of olive millwastewater.
\end{abstract}

Keywords: Olive mill, Coagulation, Electrocoagulation, Anaerobic, Aerobic .

\section{Introduction}

Treatment and disposal of olive mill wastewater (OMW) represent one of the main problems for olive oil producing countries of the Mediterranean area like Egypt. The average amount of olive mill wastewater produced during the milling process is $1.2-1.8 \mathrm{~m}^{3}$ ton $^{-1}$ of olives. OMW resulting from the production processes in the Mediterranean region surpasses 30 million $\mathrm{m}^{3}$ per year [1]. The improper disposal of OMW into the environment, or to urban wastewater treatment plants, is prohibitive due to its potential threat to surface and groundwater, or due to its toxicity to microorganisms used in treatment plants. Despite being recognized as a hazardous residue, land disposal of OMW remains the most diffused approach along the Mediterranean basin [2]. Phyto-toxic effects on soil properties have been reported to occur when this waste is used directly as an organic fertilizer [3]. In addition, the acidic $\mathrm{pH}$ and the polyphenols' complexing abilities increase the solubility of heavy metals in the environment [4].
Several methods were tested for the treatment of OMW such as mechanical, physical, chemical, biological and thermal method. Various physicochemical processes such as coagulation/ flocculation and membrane filtration have also been employed for the OMW treatment. The use of direct flocculation with polyelectrolytes for the treatment of OMW showed that two polyelectrolytes, one anionic and one cationic, failed to yield separation, whereas a minimum dose of $2.3 \mathrm{~g} /$ Lwas required. Nearly complete reduction of solids was observed in subsequent analysis, while COD and BOD reduction was up to 55 and $23 \%$, respectively $[5,6]$

The problems associated with the OMW are mainly related to its toxic character due to the presence of phenolic compounds, which cannot be degraded by biological treatment [7]. Electrocoagulation (EC) is an electrochemical method of treating polluted water whereby sacrificial anodes dissolve to produce active coagulant precursors (usually aluminum or iron cations) in the solu- 
tion. This technology can be used for the removal of both color and colloidal particles [8]. EC has been successfully used for the treatment of wastewaters from food industries such as dairy[9] and alcohol distillery [10]. EC processes have been widely used to treat wastewater with a high quantity of oil-grease, COD, and toxics such as olive oil mill wastewater [11]. The combined biological treatment of fresh lye and washing water from green table olive processing and advanced oxidation, using an electrochemical system, is a viable option to reduce the COD by $97 \%$ [12]. Conventional biological processes (aerobic or anaerobic) have shown moderate efficiencies in terms of OMW mineralization [13]. Aerobic treatment of OMW by three microorganisms, namely Geotrichum sp., Aspergillus sp. and Candida tropicalis , led to an average reduction in terms of COD to $52.5 \%, 44.3$ and 51.7\%, respectively [14]. Anaerobic processes have resulted in $60-70 \%$ of COD removal [15]. Through the years, researchers have tested a variety of technologies for OMW treatment. It is evident from the literature, that a single process cannot offer an efficient and viable solution to the problem [6].

The main objective of this study is to investigate most effective technique for the treatment of olive mil wastewater. The investigated techniques were coagulation/flocculation, electrocoagulation, anaerobic-aerobic treatment and electrocoagulation-aerobic treatment.

\section{Materials and Methods}

\section{Wastewater sampling and analysis}

The study was carried out on a real industrial wastewater collected from Egyptian canning company is a global market leader in the field of prickling processing and packaging of the olives, also produce olive oil. The company has 3 production line or factories namely; pickling green olive, oxidation of olive "Black olive", oil production line. The estimated wastewater produced from the three production line was $466 \mathrm{~m}^{3} / \mathrm{d}$. Due to the great variation in the quantity and the quality of wastewater produced during the working day, a continuous monitoring program was carried out to identify the quality and quantity of wastewater discharged. Composite samples were collected during the working shifts for four weeks and then were subjected to physicochemical analysis according to "Standard Methods for water and wastewater, APHA, 2012[16]. The

Egypt.J.Chem. 61, No.3 (2018) analysis of wastewater samples was carried out at Water Pollution Research Lab, national research center. The analysis included $\mathrm{pH}$, Total suspended solids (TSS), Settleable solids, total dissolved solids (TDS), chemical oxygen demand (COD), biological oxygen demand (BOD), oil and grease, and all extractable matter by chloroform.

\section{Treatment techniques \\ Coagulation/Flocculation}

There are various inorganic coagulants which can be used as coagulants such as Iron sulfate II, ferric chloride III, lime and inorganic polymer floccules. In this research, different coagulants like Alum and Poly aluminum chloride (PAC) with dose 350-500 mg/l and $125-150 \mathrm{mg} / \mathrm{l}$ respectively. Jar testing was used to adjust the amount of treatment chemicals and the sequence in which they are added to samples of raw water held in jars or beakers. The sample is then stirred so that the formation, development, and settlement of floc can be watched just as it would be in the full-scale treatment plant (Floc forms when treatment chemicals react with material in the raw wastewater and clump together)[17].

\section{Electro-Coagulation}

For the batch electrocoagulation; setup reactor (the first version) according to registered patent no 2004/2017. The reactor made of glass material with the dimensions of $11 \mathrm{~cm} \mathrm{x} 11 \mathrm{~cm}$ $x 17 \mathrm{~cm}$. The working volume of the reactor was $2 \mathrm{~L}$. The EC unit consisted of two effective Aluminum electrodes in cylindrical shape connected as a bipolar system in the reactor and DC power supply. The schematic representation of the experimental setup is shown in Fig 1. After the initial characterization of wastewater, batch experimental studies were conducted to optimize the various parameters such as $\mathrm{pH}$, electrolysis time (ET) and voltage. Experiments were performed with two electrodes connected to the DC power supply to determine optimum operating conditions. The space between the two electrodes was fixed in all the experiments. In each run, the voltage was varied to the desired value of 30 volts. To maintain homogenous mixing of the reactor content, the magnetic stirring unit is used. The EC experiments were performed for 2 hours and in each run, samples were collected at every 30-minute interval for necessary analysis. Figure 1 shows a schematic diagram of the electrocoagulation treatment unit. 


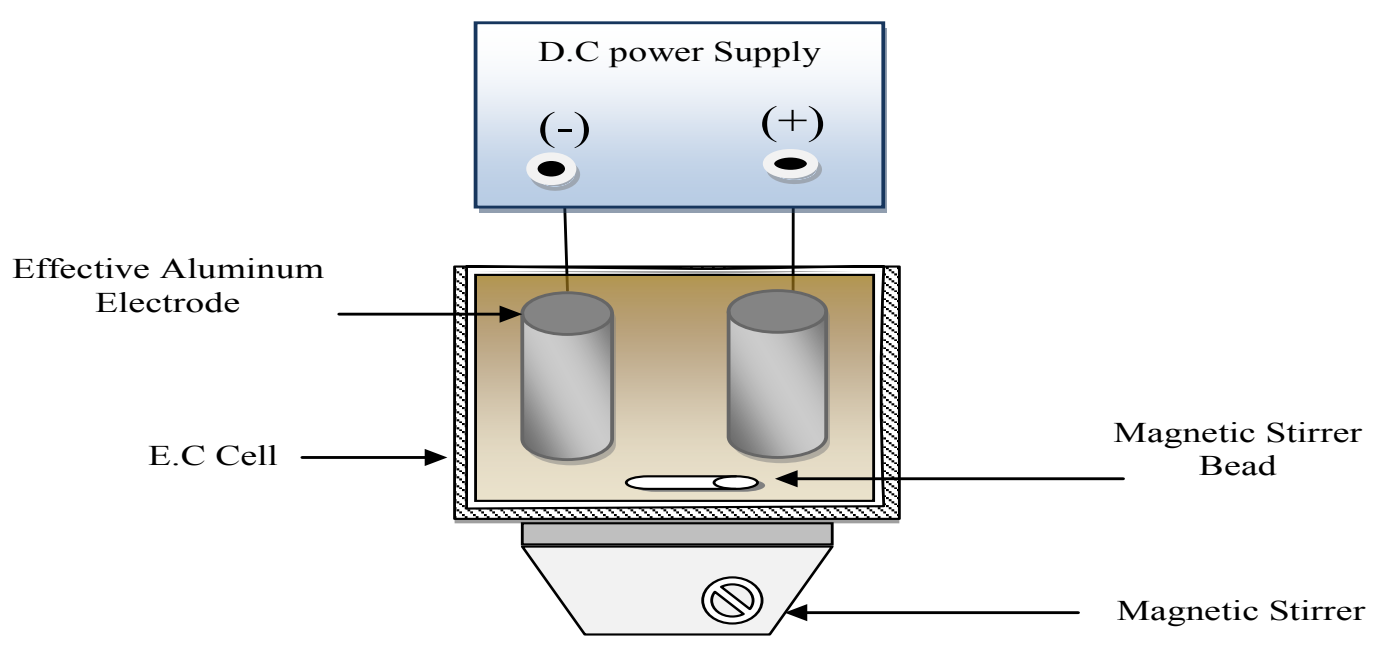

Fig.1. Schematic diagram of electrocoagulation treatment unit.

\section{Anaerobic-aerobic treatment}

Anaerobic treatment was carried out in a reactor with 5 liters volume. The effective volume of the reactor was 3 liters and it was operated at room temperature $\left(25^{\circ} \mathrm{C}\right)$ with continuous shaking. The reactor was feed with digested sludge from a wastewater treatment plant in Cairo. Anaerobic conditions have been established initially by bubbling nitrogen for $5 \mathrm{~min}$. The reactor was fed in a batch mode with raw OMWW each $24 \mathrm{~h}$. After one month of operation, the treatment efficiency was stabilized and monitoring of the performance was conducted. Figure 2 shows a schematic diagram of the anaerobic treatment unit.
The set-up of aerobic treatment consisted of two cylindrical columns with a volume of 2 liters for each one. One column was subjected to the treatment of anaerobic effluent while the other was used for the treatment of electrocoagulation effluent. The two reactors were inoculated with acclimatized activated sludge which was delivered from a wastewater treatment plant in Cairo. The sludge volume was maintained at 300 $\mathrm{ml} / 1$ while the sludge weight was $3 \mathrm{~g} / \mathrm{l}$. DO was adjusted to be around $4 \mathrm{mg} / \mathrm{l}$. Wastewater in the reactors was aerated by an air pump and diffusers. For comparison, the hydraulic retention time was kept constant at $24 \mathrm{~h}$ for all reactors.

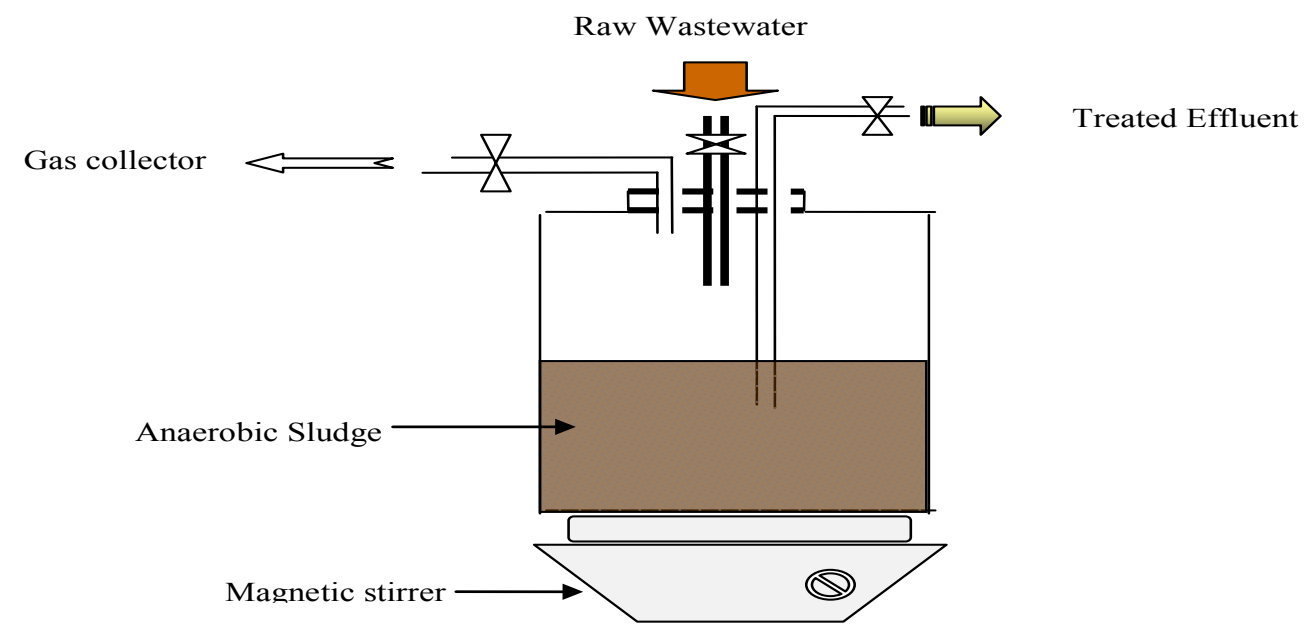

Fig.2. Schematic diagram of the anaerobic treatment unit. 


\section{$\underline{\text { Results and Discussion }}$}

Characterization of Raw wastewater

Physico-chemical characterization of industrial wastewater is depicted in Table 1. The analysis showed a great variety of organic contents in terms of COD, BOD. Also, the total dissolved solids concentration was very high due to pickling process.

\section{Coagulation/Flocculation}

The effect of coagulation/flocculation on the treatment of olive mill wastewater using poly aluminum chloride(PAC) and aluminum sulfate is shown in Fig. 3. With a dose of 125 and 150 $\mathrm{mg} / \mathrm{l}$ of PAC, the removal efficiency reached $6 \%$ and $11 \%$ respectively. However, better removal efficiencies were achieved using aluminum sulfate with dose 350,400 and $500 \mathrm{mg} / \mathrm{l}$ resulted in a removal rate $25 \%, 51 \%$ and $54.7 \%$ respectively. These results are in agreement with Fatta-Kassinos et al [6] who reported that the removal of COD can reach $25 \%$ by coagulation/ flocculation process. The salinity of wastewater was high which affected the treatment efficiency. Lefebvre and Moletta reported that coagulationflocculation can be used as a pretreatment of hypersaline effluents to remove their colloidal COD [18].

TABLE 1. Characterization of raw wastewater

\begin{tabular}{|c|c|c|c|c|c|}
\hline \multicolumn{2}{|l|}{ Parameters } & Unit & Maximum & Minimum & Average \\
\hline \multicolumn{2}{|l|}{$\mathrm{pH}$} & -- & 5.8 & 4.5 & 5.6 \\
\hline \multicolumn{2}{|c|}{ Total Suspended Solids } & $\mathrm{mg} / \mathrm{l}$ & 2400 & 1020 & 1622 \\
\hline \multicolumn{2}{|c|}{ Total Dissolved Solids } & $\mathrm{mg} / 1$ & 14830 & 7000 & 10032 \\
\hline \multicolumn{2}{|c|}{ Electrical Conductivity } & $\mu \mathrm{Sem} / \mathrm{cm}$ & 24400 & 14000 & 18675 \\
\hline \multirow{2}{*}{ Setteable Solids } & 10 minute & $\mathrm{ml} / 1$ & 10 & 0.5 & 5.7 \\
\hline & 30 minute & $\mathrm{ml} / 1$ & 11 & 0.6 & 6.9 \\
\hline \multicolumn{2}{|c|}{ Chemical Oxygen Demand } & $\mathrm{mg} / \mathrm{l}$ & 11400 & 5887 & 9174 \\
\hline \multicolumn{2}{|c|}{ Soluble Chemical Oxygen Demand } & $\mathrm{mg} / \mathrm{l}$ & 7860 & 2930 & 5689 \\
\hline \multicolumn{2}{|c|}{ Biological Oxygen Demand } & $\mathrm{mg} / \mathrm{l}$ & 5820 & 2216 & 4426 \\
\hline \multicolumn{2}{|c|}{ Oil \& Grease } & $\mathrm{mg} / 1$ & 980.7 & 875.3 & 914.8 \\
\hline
\end{tabular}

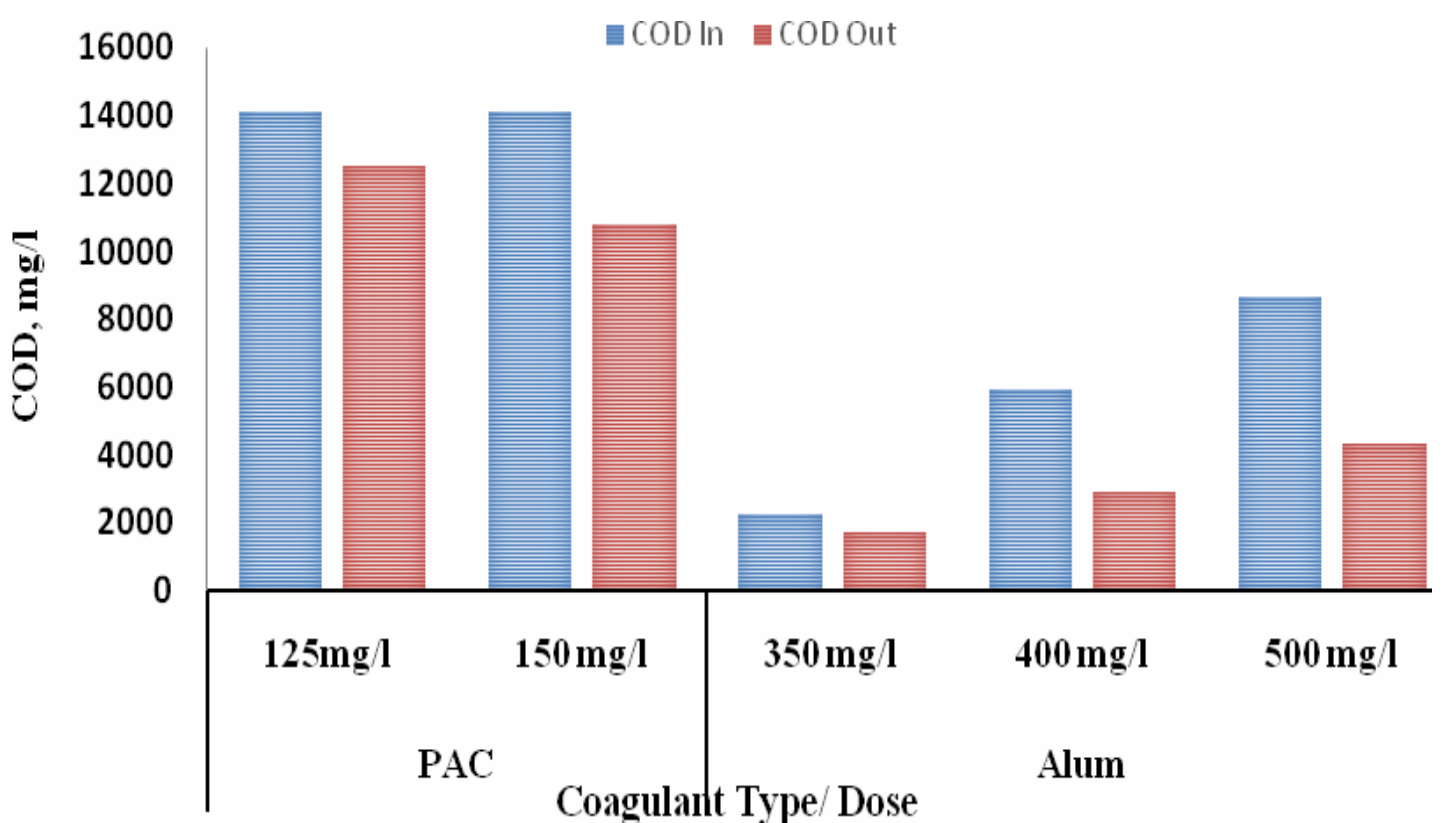

Fig. 3. Coagulation/flocculation with PAC and Alum at different doses. 


\section{Electro-Coagulation}

This part of the study was mainly focused on the electrocoagulation of the olive mill wastewater with high concentration of COD for determining effects of operating parameters such as $\mathrm{pH}$, TDS and electrolysis time on COD removal. The results depicted in Table 2. Initially, apply the experiment without adjusting $\mathrm{pH}$ of raw wastewater; at $\mathrm{pH}$ 5 with varying time. Figure 4 illustrates the variation of COD, TDS, and $\mathrm{pH}$ during different electrolysis time. The results indicated that there is a linear relation between COD reduction and electrolysis time. The percentage removal of COD after 30 minutes was 55\%; however, removal efficiency reached to $84 \%$ for COD at 1.5 hours. The results showed also no significant decrease in TDS concentration. However, a slight increase in $\mathrm{pH}$ was observed. The treated effluents still need further treatment. Accordingly, aerobic treatment of the effluent from EC was applied.

\section{Biological Treatment \\ Anaerobic Treatment followed by aerobic treatment.}

Anaerobic treatment methods are known to be more suitable for the treatment of concentrated high saline waste for the following reasons: offer lower operating costs, produce energy (biogas) and less sludge with a better quality as compared to aerobic treatment. After one month of operation, the treatment efficiency was stabilized and monitoring of the performance was conducted. The results obtained are depicted in Table 2. With regard to ammonia, an increase in its concentration has been reported in the effluent of all anaerobic reactors. This is a result of the ammonification of organic nitrogen. These results are higher than El-Gohary et al [1] that reported that of the removal of COD in anaerobic digestion is $34 \%$ and in our study, the removal of COD reached $74 \%$.

TABLE 2. Performance of electrocoagulation on wastewater treatment.

\begin{tabular}{lcccc}
\hline Parameter & Unit & Raw & Electrocoagulation & \% Removal \\
\hline $\mathrm{pH}$ & -- & 5 & 7.00 & -- \\
Total suspended solids & $\mathrm{mg} / 1$ & 3420 & 556 & 84 \\
Total Dissolved Solids & $\mathrm{mg} / 1$ & 16500 & 26000 & 3 \\
Electrical conductivity & $\mathrm{ms}$ & 26.1 & 25.5 & 2 \\
Chemical oxygen demand & $\mathrm{mgO} / 1$ & 11400 & 20 & 84 \\
Total Kjeldahl Nitrogen & $\mathrm{mg} / \mathrm{l}$ & 54 & 0.1 & 83 \\
Total Phosphorus & $\mathrm{mg} / 1$ & 16 & 83 & 99 \\
Oil and grease & $\mathrm{mg} / 1$ & 3169 & & 97 \\
\hline
\end{tabular}

TABLE 3. Anaerobic treatment for raw wastewater.

\begin{tabular}{lcccc}
\hline Parameter & Unit & Influent & Effluent & \% Removal \\
\hline $\mathrm{pH}$ & - & 5.3 & 6.3 & - \\
$\mathrm{COD}$ & $\mathrm{mgO}_{2} / 1$ & 11400 & 2930 & 74.5 \\
$\mathrm{TKN}$ & $\mathrm{mg} \mathrm{N} / 1$ & 144 & 120 & - \\
$\mathrm{TSS}$ & $\mathrm{mg} / 1$ & 2120 & 470 & 77.8 \\
\hline
\end{tabular}

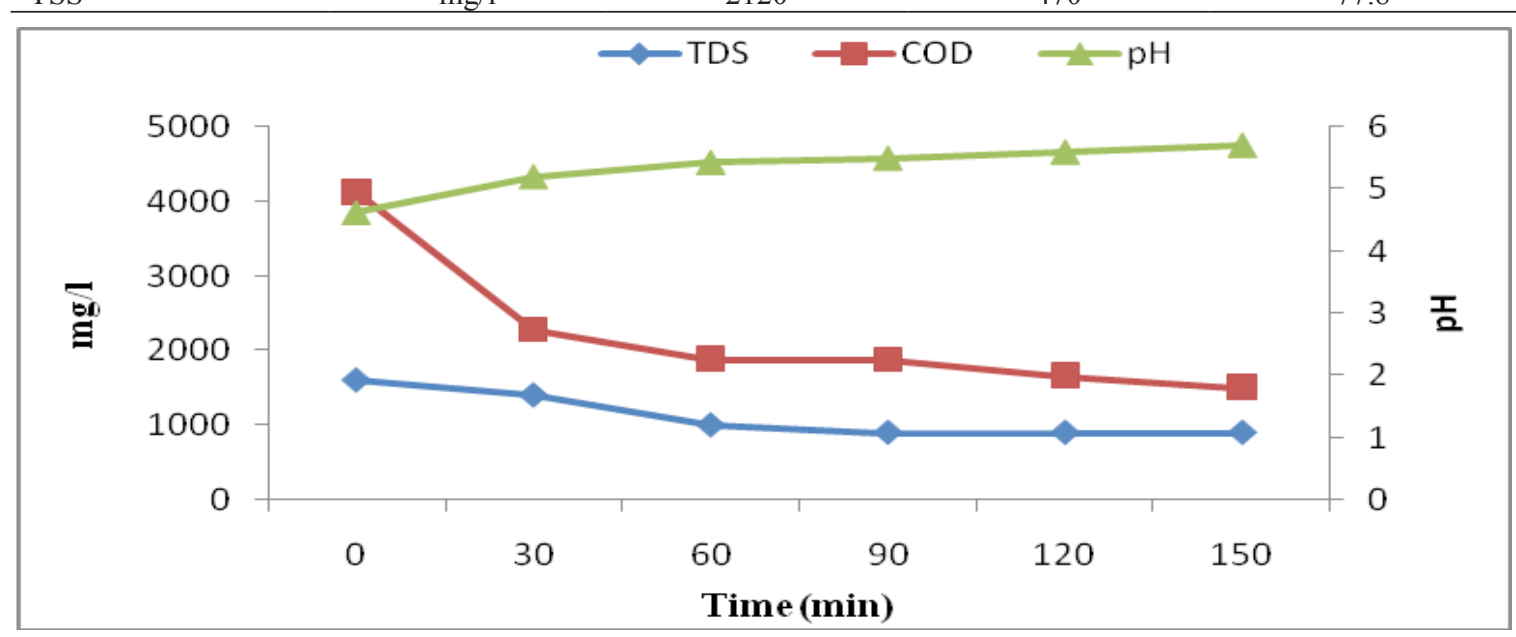

Fig. 4.TDS, COD, and pH variation over time using electrocoagulation. 
Aerobic treatment after electrocoagulation

Table 4 shows the efficiency of aerobic treatment applied after electrocoagulation treatment. Wastewater another possible strategy consists in inoculating a mixture of halophilic organisms issued from diverse natural saline environments, such as salterns, in order to bring the organisms that will be able to stand high salt concentrations and treat the pollution at the same time. Such strategy has been employed, for instance, by [19] to treat various industrial saline wastewater.

TABLE 4. Overall efficiency for treatment module.

\begin{tabular}{|c|c|c|c|c|c|c|}
\hline Parameter & Unit & Raw & EC. Effluent & Aerobic Effluent & $\begin{array}{c}\text { Overall \% } \\
\text { removal }\end{array}$ & $\begin{array}{c}\text { Ministerial } \\
\text { Decree } \\
44 / 2000 \\
\end{array}$ \\
\hline $\mathrm{pH}$ & -- & 7 & 9.4 & 8.5 & -- & $6-9.5$ \\
\hline TDS & $\mathrm{mg} / 1$ & 10638 & 6450 & 1170 & 89 & --- \\
\hline TSS & $\mathrm{mg} / \mathrm{l}$ & 1634 & 253.5 & 98 & 94 & 800 \\
\hline $\mathrm{COD}$ & $\mathrm{mg} / \mathrm{l}$ & 7700 & 900 & 385 & 95 & 1100 \\
\hline
\end{tabular}

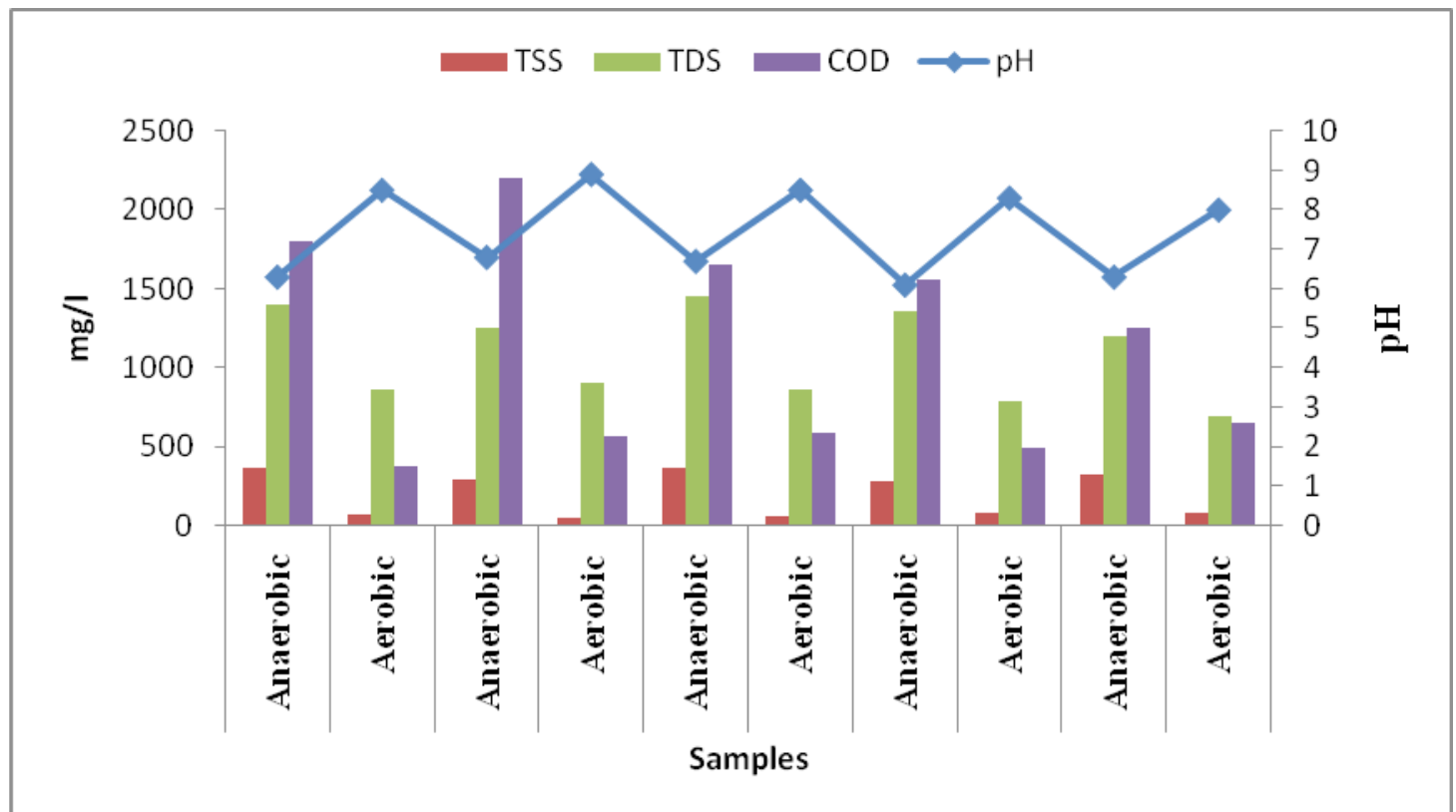

Fig.5. Variation of COD, TDS, TSS and pH concentration and \% removal anaerobic-aerobic

\section{Conclusion}

Based on the experimental findings, coagulation/flocculation was not effective insoluble organic load removal. The maximum removal rate of COD reached $51 \%$ only using aluminum sulfate. Electrocoagulation technique achieved COD removal rate 84\%. Although the application of anaerobic treatment for olive wastewater achieved COD removal rate of $74 \%$, the residual concentration was very high. Aerobic treatment using activated sludge was applied after electrocoagulation and anaerobic treatment. The results showed that the use of aerobic treatment after electrocoagulation is more efficient than Egypt.J.Chem. 61, No.3 (2018) the use of anaerobic. The analysis of the treated water showed that the maximum COD removal efficiencies were $95 \%$ at optimum conditions. The effluent was very clear and its quality meets the discharge standard. Hence, it can be concluded that the electrocoagulation technology using aluminum electrodes followed by aerobic treatment appears to be a feasible alternative for the treatment of olive industry wastewater. Thus electrocoagulation is an efficient process for treatment of such industry wastewater which is fast, easy, and economical and can be operated using less equipment and limited space. 


\section{Acknowledgment}

The authors acknowledge National Research Centre, Egypt for the financial support of this work through the project No. P100809.

\section{References}

1. El-Gohary F. A., Badawy M. I., El-Khateeb, M. A. and El-Kalliny A. S., Integrated treatment of olive mill wastewater (OMW) by the combination of Fenton's reaction and anaerobic treatment, J. Hazard. Mater., 162 (2-3), 1536-1541(2009).

2. Paredes C., Bernal M. P., Roig A., and Cegarra J., Effects of olive mill wastewater addition in composting of agroindustrial and urban wastes, Biodegradation, 12(4), 225-234 (2001).

3. Gernjak W., Maldonado M. L., Malato S., Cáceres J., Krutzler T., Glaser A., and Bauer R., Pilot-plant treatment of olive mill wastewater (OMW) by solar TiO2photocatalysis and solar photo-Fenton, Sol. Energy, 77(5), 567-572 (2004).

4. Wahaab R. A., Moawad A. K., Taleb E. A., and Ibrahim H. S., Combined Photocatalytic Oxidation and Chemical Coagulation for Cyanide and Heavy Metals Removal from Electroplating Wastewater, 8(4), 462-469 (2010).

5. Sarika R., Kalogerakis N., and Mantzavinos D., Treatment of olive mill effluents: Part II. Complete removal of solids by direct flocculation with polyelectrolytes, in Environment International, 31, no. 2, 297-304 (2005).

6. Michael I., Panagi A., Ioannou L. A., Frontistis Z., and Fatta-Kassinos D., Utilizing solar energy for the purification of olive mill wastewater using a pilot-scale photocatalytic reactor after coagulation-flocculation, Water Res., 60, 28-40 (2014).

7. Martins R. C. and Quinta-Ferreira R. M., Remediation of phenolic wastewaters by advanced oxidation processes (AOPs) at ambient conditions: Comparative studies, Chem. Eng. Sci., 66 (14), 3243-3250 (2011).

8. Essadki A. H., Bennajah M., Gourich B., Vial C., Azzi M., and Delmas H., Electrocoagulation/electroflotation in an external-loop airlift reactor-Application to the decolorization of textile dye wastewater: A case study, Chem. Eng. Process. Process Intensif., 47 (8), 12111223 (2008).

9. Şengil I. A. and özacar M., Treatment of dairy wastewaters by electrocoagulation using mild steel electrodes, J. Hazard. Mater., 137 (2), $1197-$ 1205 (2006).

10. Yavuz Y., EC and EF processes for the treatment of alcohol distillery wastewater, Sep. Purif. Technol., 53 (1), 135-140 (2007).

11. García-García P., López-López A., MorenoBaquero J. M., and Garrido-Fernández A., Treatment of wastewaters from the green table olive packaging industry using electrocoagulation, Chem. Eng. J., 170 (1), 59-66 (2011).

12. Kyriacou A., Lasaridi K. E., Kotsou M., Balis C., and Pilidis G., Combined bioremediation and advanced oxidation of green table olive processing wastewater, Process Biochem., 40 (3-4), 14011408 (2005).

13. Ouzounidou G., Georgios Z. I., and Gaitis F., Raw and Microbiologically Detoxified Olive Mill Waste and their Impact on Plant Growth, Terr. Aquat. Environ. Toxicol., 4 (1), 21-38 (2010).

14. Fadil K., Chahlaoui A., Ouahbi A., Zaid A., and Borja R., Aerobic biodegradation and detoxification of wastewaters from the olive oil industry, Int. Biodeterior. Biodegrad., 51 (1), 37-41 (2003).

15. Martinez-Garcia G., Johnson A. C., Bachmann R. T., Williams C. J., Burgoyne A., and Edyvean R. G. J., Anaerobic treatment of olive mill wastewater and piggery effluents fermented with Candida tropicalis, J. Hazard. Mater., 164 (2-3), 1398-1405 (2009).

16. APHA/AWWA/WEF, "Standard Methods for the Examination of Water and Wastewater," Stand. Methods, p. 541, (2012).

17. Abou-taleb E. M., Nazih M., Hellal M. S., and Sohair I., Treatment of Yarn Dyeing Wastewater Using Different Coagulants Followed by Activated Carbon Adsorption, 4531, 327-339 (2014).

18. Justino C. I., Duarte K., Loureiro F., Pereira R., Antunes S. C., Marques S. M., Gonçalves F., Rocha-Santos T. A. P., and Freitas A. C., Toxicity and organic content characterization of olive oil mill wastewater undergoing a sequential treatment with fungi and photo-Fenton oxidation, J. Hazard. Mater., 172 (2-3), 1560-1572 (2009).

19. Lefebvre O. and Moletta R., Treatment of organic pollution in industrial saline wastewater: A literature review, Water Research, 40 (20), 3671 3682 (2006).

(Received 28/1/2018; accepted 16/4/2018)

Egypt.J.Chem. 61, No.3 (2018) 


\section{دراسة تقنيات المعالجة الفعالة لمياه الصرف الصناعى لمصانع الزيتون}

إيناس ابوطالب، جمال كامل، محمد هلال

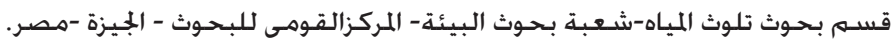

إن اختيار وحدات معالجة فعالة من حيث التكلفة لمياه الصرف الصناعى عالية الملوحة الناتجة عن صناعة التهاء

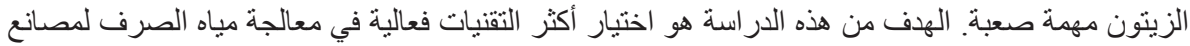

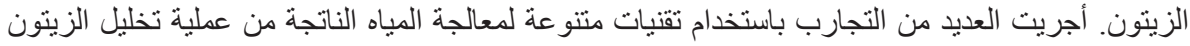

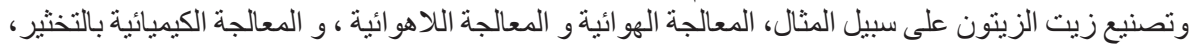

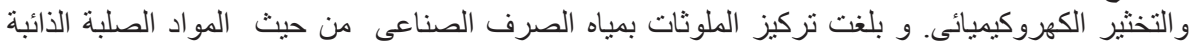
و الاحتياج الأكسجينى الكيميائي(COD) و الزيزئ (COD)

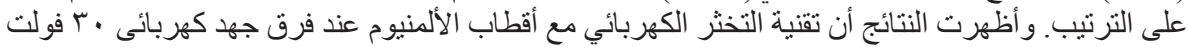

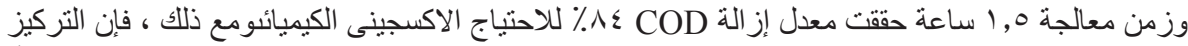

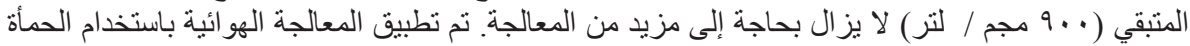

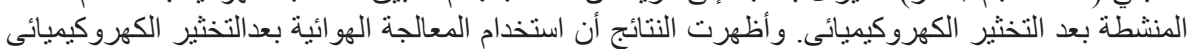

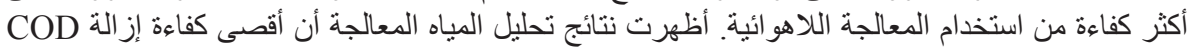

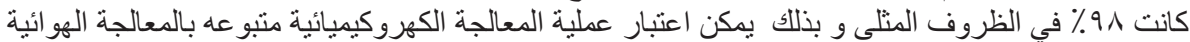
كطريقة آمنة وفعالة من حيث التكلفة لمعالجة مياه الصرف الصناف الصناعى لمصانع الزيتون. 